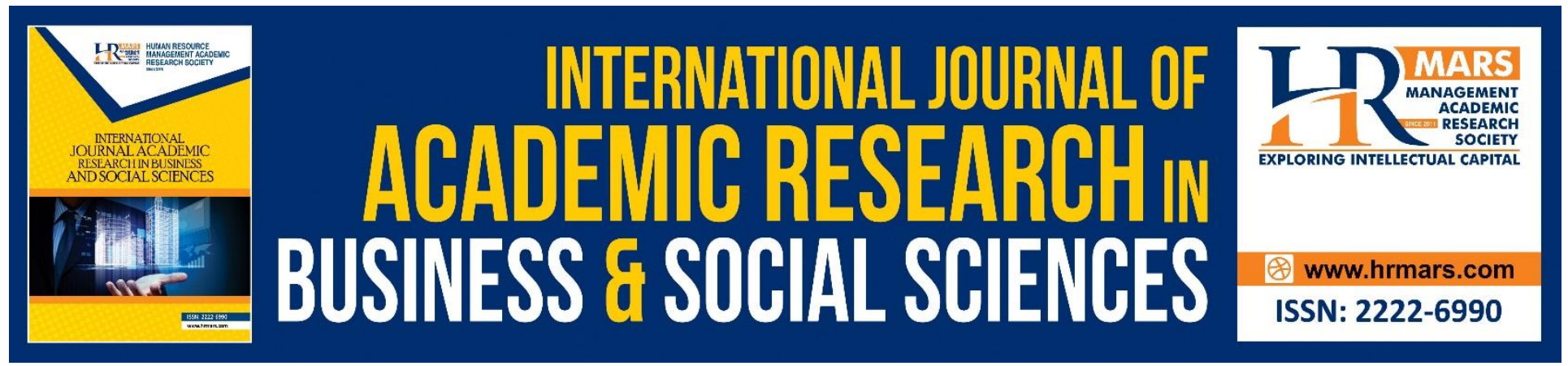

\title{
An Investigation of the Impact of Occupational Stress on Employee Performance: Evidence from the Ghanaian Banking Sector
}

Nana Serwaa Yeboah-Kordee, Kwesi Amponsah-Tawiah, Isaac Nyarko Adu, Augustina Adei Ashie

To Link this Article: http://dx.doi.org/10.6007/IJARBSS/v8-i9/4581

DOI: $\quad 10.6007 /$ IJARBSS/v8-i9/4581

Received: 09 July 2018, Revised: 26 August 2018, Accepted: 29 August 2018

Published Online: 28 September 2018

In-Text Citation: (Yeboah-Kordee, Amponsah-Tawiah, Adu, \& Ashie, 2018)

To Cite this Article: Yeboah-Kordee, N. S., Amponsah-Tawiah, K., Adu, I. N., \& Ashie, A. A. (2018). An Investigation of the Impact of Occupational Stress on Employee Performance: Evidence from the Ghanaian Banking Sector. International Journal of Academic Research in Business and Social Sciences, 8(9), 150-169.

Copyright: (C) 2018 The Author(s)

Published by Human Resource Management Academic Research Society (www.hrmars.com)

This article is published under the Creative Commons Attribution (CC BY 4.0) license. Anyone may reproduce, distribute, translate and create derivative works of this article (for both commercial and non-commercial purposes), subject to full attribution to the original publication and authors. The full terms of this license may be seen

at: http://creativecommons.org/licences/by/4.0/legalcode

Vol. 8, No. 9, September 2018, Pg. 150 - 169 


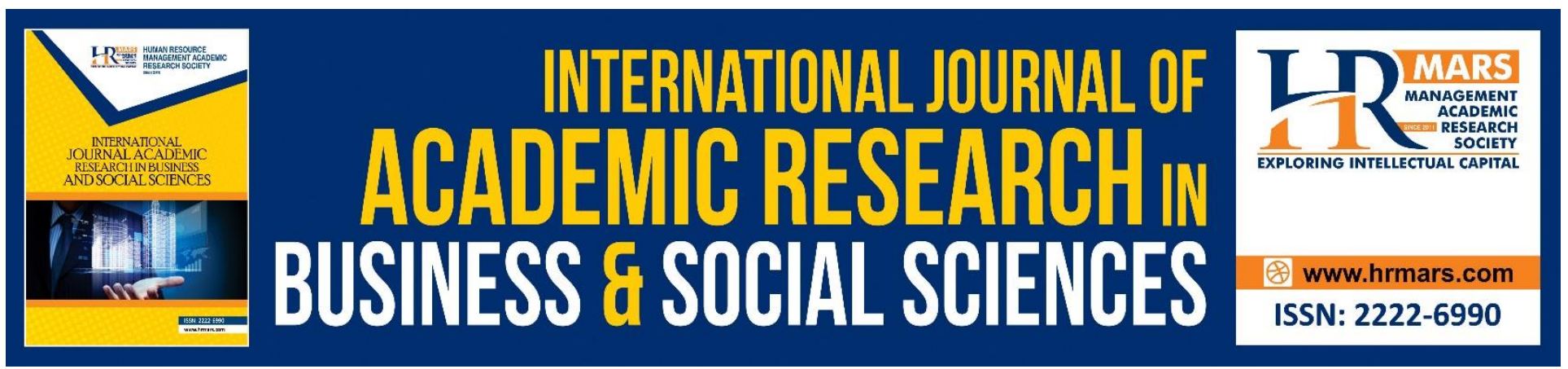

\title{
An Investigation of the Impact of Occupational Stress on Employee Performance: Evidence from the Ghanaian Banking Sector
}

\author{
Nana Serwaa Yeboah-Kordee ${ }^{1}$, Kwesi Amponsah-Tawiah², Isaac \\ Nyarko Adu $\mathrm{a}^{*}$, Augustina Adei Ashie ${ }^{3 \mathrm{~b}}$ \\ ${ }^{1}$ All Nations University College, Koforidua-Ghana, Human Resource Management Department, \\ Koforidua, Email: Nanaserwaa.yeboah@gmail.com \\ ${ }^{2}$ University of Ghana Business School, Department of Organisational and Human Resource \\ Management, Legon-Accra, Email: kamponsah-tawia@ug.edu.gh \\ 3*University of Education, Winneba-Ghana, Department of Business Education \\ Winneba-Ghana, Email: ainadu@uew.edu.gh/_baashie@uew.edu.gh
}

\begin{abstract}
This study sought to discover the potential sources of occupational stress in the Ghanaian Banking Sector and their impact on employee performance. The quantitative methodology was employed using survey instrument. Convenience sampling was used to select four top performing banks listed in the Ghana club 100 rankings. Approximately 320 respondents were selected for the study. Occupational stress had a negative significant relationship with employee performance. However occupational role was positively related with employee performance, on the other hand, personal strain was found to be a potential source of occupational stress for bankers which reduced their ability to perform. Coping strategy served as a moderator that reduced the influence of occupational stress on bankers' performance. The study concludes that, the impacts of occupational stress on bankers' performance are not necessarily negative; this is also seen to be very important in the workplace.
\end{abstract}

Keywords: Occupational Stress, Coping Strategy, Employee Performance, Bankers

\section{Introduction}

Stress is one of the most serious workplace elements experienced by employees around the world. It has become a major danger for employers especially in developing nations where employers take very little notice of the impact of stress on employee performance resulting in critical managerial dilemmas (Subha \& Shakil, 2010). Giga and Hoel (2003) argues that high degrees of increasing economic interdependence among countries due to globalization, mergers, acquisitions, technological development, and restructuring have changed the organizational work over the last 
INTERNATIONAL JOURNAL OF ACADEMIC RESEARCH IN BUSINESS AND SOCIAL SCIENCES Vol. 8, No. 9, Sept. 2018, E-ISSN: 2222-6990 @ 2018 HRMARS

few decades resulting in time pressure, excessive work demand, role conflicts, ergonomic insufficiencies and problematic customer relationship is causing excessive stress.

Occupational stress researchers agree that stress is a grave problem in organizations (Khamisa, et. al., (2015); Tsai, et al. (2017). The cost of occupational stress is highly estimated in many organizations. For instance, the International Labour Organization (ILO) reports that inefficiencies arising from occupational stress may amount to 10 percent of a country's Gross national product (GNP) (Mills et al. (2017). At a personal level, occupational stress might lead to increased morbidity and mortality (Venugopal, et al., 2016). Mwangi, (2015) mentions that work related stress influences the performance of individuals and result in unwanted behaviours such as smoking and drinking and also cause depression and anxiety when they are not able to meet the conflicting demands and responsibilities of their jobs. The National Institute for Occupational Safety and Health (2010) assert that with the passage of time, working conditions have evolved a lot and work stress has been a focus for much more importance because it is a hidden devil which can shape the performance of individuals as well as of working organizations.

The workplace is potentially an important cause of stress for bankers because of the quantity of time they expend in their respective banks (Jamshed et al., 2011). The financial security, opportunities for advancement, demands to perform, relations, events, and physical environment at the workplace affect an individual's ability to cope in the work environment (Carayon et al., 2015; Eldor, et al., 2017). Consequently, the occupation of individuals could be a key cause of stress in the given circumstances. Powell, (2018) defines occupational stress as any discomfort which is felt and recognized at a personal level and prompted by instances, events or situations that are too extreme and recurrent in nature so as to surpass a person's coping capabilities and resources to handle them satisfactorily. Stress is the response by the body to the demands placed on it; the individual's capacity to cope with this demand will determine the level of stress the person is faced with. On the other hand, employee performance is defined as the results and achievements expected of the employee who are esteemed by the organization or system that he or she works in (Rebecca, 2010). Many employees account that their jobs are a basis of huge amount of stress and have very dreadful and negative consequences on their performance (McGann, et al., 2016)

As a result, occupational stress is regarded as a challenge for the employers and since high altitude of stress results in low output, and other employee problems it is indispensable that managers find a solution to the issue of occupational stress (Elovainio et al., 2002). When individuals face stress owing to an assortment of conditions of their occupation and fail to cope with them, it results into burnout. In the banking sector, deficiencies in administrative support from managers, work overload and time pressure, poor relationship with customers and coworkers, and work life balance cause stress which in turn lessen employee performance. According to Manu (2016) causes of stress are numerous including work load, cuts in staff, change at work, long work hours, lack of supervision, insufficient training, improper working conditions, too heavy responsibilities and poor relations with colleagues. McGann, et al., (2016) proposed that stress related to job can be regularly restrained because of its probable threats to both group and individual performance. Job related stress can result in a disparity amid demands on groups and teams at the workplace and the ability of the groups to offer give off their collective best for the improvement of the organisation. The inability of employees to sustain a practical balance between family life and work life results in work to family conflicts which in turn cause stress and eventually diminish employee's performance (McGann, et al., 2016).

Employees working in the banking the sector are under continuous feeling of uncertainty due to the prevailing economic slump in the financial sector around the globe and there are no signs of recovery, 
INTERNATIONAL JOURNAL OF ACADEMIC RESEARCH IN BUSINESS AND SOCIAL SCIENCES

Vol. 8, No. 9, Sept. 2018, E-ISSN: 2222-6990 @ 2018 HRMARS

which is a cause of worry for the workers and may lead towards stress (Kazmi, et al., 2017). Larson (2004) indicates that career progression generates stress on employee's understandings of the value of his or her career prospects. Barriers in career advancement can appear at any time throughout an employee's employment period which serves as stressor for them. These stressors can incorporate an array of problems like being fixed at a position without any hopes of advancement or threats of downsizing (Wan et al., 2014).

Quick and Henderson (2016) emphasized that stress can lead to serious glitches in the workplace which unconstructively affect employee wellbeing and organizational productivity. Stress can bring about problems such as low commitment, job dissatisfaction, alcoholism, absenteeism, physical ailment and reduced job performance. If managers know how to avoid and cope with stress, productivity can be augmented. Quick and Henderson (2016) reported that a stress inventory obtainable from a stress-management program can aid executives and managers in evaluating employee stress. The inventory can make out the sources of stress, which may comprise physical elements as well as additional factors. Once these sources have been assessed, the program can provide the essential expertise for coping with the problems, and partakers can discover that there are unconventional ways of reacting to stress. In the banking sector principally, senior managers do not understand the impact of stress on employee performance which finally results in serious managerial dilemmas as portrayed by Subha and Shakil (2009)

According to Ashong et al., (2016), 60 to 70 per cent of hospital visits in Ghana in the year 2005 were stress related. Stress and lifestyle diseases are gradually becoming the main source of mortality among Ghanaians (Ashong et al., 2016). According to Ballard (2016), there is no solitary cause of job stress. While stress can be triggered by sudden, unanticipated pressures, it is frequently the result of a blend of stressful factors which accrue over time. Some people can turn out to be so used to the warning signs of excessive stress that it disregarded to their detriment. Most job stress arise out of management of work, relationships at work, organizational setup and the level of one's competencies in performing his duties.

The banking profession is inherently stressful due to the long working hours, stiff competition, relationships at work, regulatory bottlenecks and difficult customers that characterizes every activities (Dartey-Baah \& Ampofo, 2015). If the influence of occupational stress on staff performance is properly assessed and the right mechanisms put in place to reduce it, the issue of occupational stress among Ghanaian bank workers will be addressed. The question of how occupational stress influences employees' performance is relevant given the nature of today's banking environment and the challenges faced by Ghanaian employees (Dartey-Baah \& Ampofo, 2015).

\section{Hypotheses}

$\mathrm{H} 1$ : There will be a significant negative correlation between occupational stress and job performance amongst employees in the Ghanaian Banking Sector

$\mathrm{H}$ 2: There will be a significant positive relationship between coping strategies and work performance amongst employees in the Ghanaian Banking Sector

H3: Occupational stress will negatively influence work performance amongst employees in the Ghanaian Banking Sector 
INTERNATIONAL JOURNAL OF ACADEMIC RESEARCH IN BUSINESS AND SOCIAL SCIENCES

Vol. 8, No. 9, Sept. 2018, E-ISSN: 2222-6990 @ 2018 HRMARS

H4: Coping strategies will positively influence work performance amongst employees in the Ghanaian Banking Sector

\section{Literature Review}

\section{Understanding Occupational Stress}

Stress as defined by Cheung (2016) is a condition of worry that crops up from a genuine or apparent demand that requires a change in behaviour. Stress commonly has been defined as a displeasing emotional state, which is said to happen when there have been extended, increasing or new forces that are considerably superior to the coping resources (Siegrist, 2001). Stress caused owing to a person's job or employment is termed as occupational stress. Job stress, or occupational stress is used interchangeably (Brock \& Grady, 2002). McGrath (1970, pp10-12) has provided one of the most extensively acknowledged definitions of occupational stress: "An obvious, significant inequity between demand and response ability, under situations where failure to organize the demands has major evident cost."

Jones et al., (2001) indicate that the term work-related stress has in the past been used to contain a variety of environmental stimuli, stress responses and other factors that influence the association between the two. Unmanaged stress for employees can result in health effects including tiredness, bodily pain, depression, sleep turbulence, and even demise (Brock \& Grady, 2002; LeFevre, et al., 2003).

The basis and characteristics of occupational stress has been the subject of much research. Sutherland and Cooper (2000) developed five categories of possible sources of psychosocial and occupational stress. Other factors that are potential stressors include live events that may cause stress such as home, family and demands, matrimonial troubles, and conflicts between job and family demands (Sutherland \& Cooper, 2000). It can as well be incidental that there are two dissimilar forms of stressors; those which originate from within the individual, which include personal beliefs, attitudes and self-concepts, and those that start outside the individual, which include environmental and work related stressors (Kinman \& Jones, 2001).

The aforementioned definitions clearly reflect that the researchers have viewed the idea of occupational stress in numerous ways. It is not just an environmental stimulus or response to environmental demands, but also a lively relational concept. There is constant communication between the person and the environment, which is refereed by a complex set of ongoing cognitive processes.

\section{Employee Performance}

Employee performance is this study's dependent variable (and one of the vastly considered variables in organisational psychology); it refers to "the level of productivity of an individual employee, relative to his or her peers, on several job-related behaviours and outcomes" Greenidge, \& Coyne, 2014 p.12). According to Odoardi, (2016), the direct impact of motivation on the productivity of a unit suggests the need to understand factors that affect motivation; such understanding helps managers modify conditions in the work setting to encourage individual behaviour so as to remain consistent with the organizational goals set. Nevertheless, Job performance is a multidimensional construct for which an agreement among researchers on how to conceptualise and capture has not been easy to reach. For example, Suliman (2001) suggested six dimensions namely, work skills, work duties, work enthusiasm, quality and quantity of work and readiness to innovate. Bhatti et al., (2017), captures 
INTERNATIONAL JOURNAL OF ACADEMIC RESEARCH IN BUSINESS AND SOCIAL SCIENCES Vol. 8, No. 9, Sept. 2018, E-ISSN: 2222-6990 @ 2018 HRMARS

performance in terms of quality and quantity, while Trivellas (2015) suggests the use of quality and productivity of performance.

Carlson, (2017) distinguish job performance into task and contextual performance. Task performance refers to behaviours that are directly concerned in producing commodities or services, while contextual performance involves behaviours that are not directly linked to their core task but shape the organizational, social, and psychological perspective. For example, when employees help each other, cooperate with their superiors, or make suggestions about organizational procedure, they are engaging in contextual performance (Van Scotter et al., 2000).

\section{Relationship between Occupational Stress and Employee Performance}

Stress reactions cause performance to decline in most organisations and work environments. A calm, coherent, controlled and delicate approach is more often than not called for in managing most difficult problems at work: Our social inter-relationships are just too intricate not to be damaged by an aggressive approach, while a passive and withdrawn response to stress means that we can fail to state our rights when we should (Mokdad, 2005).

The association between stress and employee performance is elucidated in one of the oldest and most central models in stress management, the "Inverted-U" relationship between pressure and performance (Gillespie et al., 2011). The Inverted-U relationship focuses on employee's performance of a task.

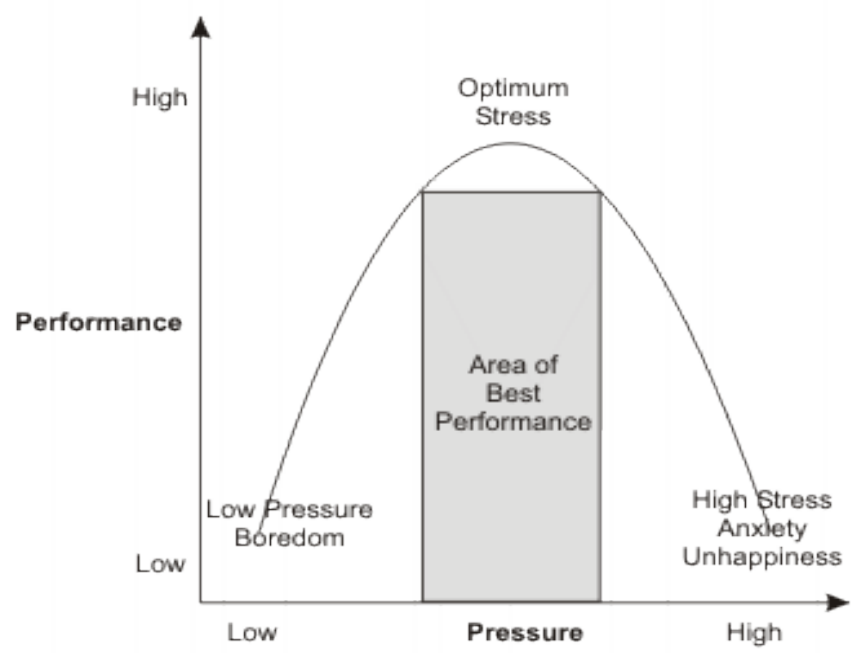

The Inverted-U relationship between pressure and performance

Figure 1: The inverted-U relationship between pressure and performance (Source from Gillespie et al., (2011)

According to Bloom, (2014), as employees become awkwardly stressed; disruptions, difficulties, anxieties and unconstructive thinking begin to crowd their minds. This is particularly the case where the meaning of stress comes in, that is, it arises when a person identifies that demands surpass the personal and social resources the individual is able to organize. These thoughts compete with performance of the task for employees' consideration, capacity and hence, concentration suffers, and focus narrows as their brains become burdened. As shown in the figure, this is something of a slippery slope: the more the brain is overloaded, the more employees' performance can suffer. The 
INTERNATIONAL JOURNAL OF ACADEMIC RESEARCH IN BUSINESS AND SOCIAL SCIENCES

Vol. 8, No. 9, Sept. 2018, E-ISSN: 2222-6990 @ 2018 HRMARS

more their performance suffers, the more new distractions, difficulties, anxieties and negative thoughts crowd their minds Gillespie et al., 2011).

\section{Employees' Stress in Relation with Performance in the Banking Sector}

A core area of the banking industry are its relationship with customers, the banking sector cannot work effectively if the employees are not provided with stress free environment, as human resources is the most important capital for the banking sector. Employees who experience stress at work due to risky work, work load, relationship problems with colleagues and the inability to manage family life also experience social problems, dissatisfaction among employees of banks and low work performance. The extreme effect of occupational stress in any bank acts as an obstruction in performance levels. Occupational stress does not just lead to turnover in banks or any other organization, but the bank may lose some of their potential employees and would have to bear high training and recruitment cost for hiring new employees.

A study on the banking sector employees by Malik (2011) showed that stress among employees of private banks is higher than the employees of public banks. The study highlighted some major stressors among employees of private and public banks which include role overload, role conflict, role authority and lack of support from senior level employees (Malik, 2011). According to Ismail and Hong (2011) lack of job clarity and predictability is the reason for role ambiguity; it is the most common factor in any working environment that affects job performance. Role ambiguity is higher in the financial industry due to the job requirements which means that employees ought to perform different set of tasks daily. Role conflict arises when an employee faces conflict between their work demands and to accomplish the work given. This conflict affects the employees work performance as a feeling of unhappiness with their work emerges (Ismail \& Hong, 2011).

The banking sector is becoming competitive day by day, as a result management are constantly adding additional responsibilities on employees that go over their capabilities which results in psychological predicaments. The Ghanaian banking sector is growing rapidly and providing opportunities for employment, but the psychological issues of occupational stress and strain may become a hurdle in the growth of the sector.

\section{Methodology}

The study is exploratory in nature due to the relative dearth of occupational stress research in Ghana (Neuman, 2007). The use of the quantitative method would help to finalize results and disprove or approve a hypothesis. The population for this research was the banking sector in Ghana. The respondents' for this study were both contract and permanent workers of four top-performing Banks in the Greater Accra Metropolis of Ghana. Both non-probability and probability sampling were adopted for this study. Also, the purposive sampling technique was adopted in selecting four top performing banks listed in the Ghana club 100. The four banks selected were Ecobank Ghana Limited (EBG), Unique Trust Bank (UTB), Zenith Bank (ZB) and Guaranty Trust Bank (GTB). The researcher used the stratified random sampling method in which the various banks identified had their departments put into strata. After that, the simple random sampling technique was employed to select the respondents from each department that took part in the research. The total population estimate for this study was 1,000. In summary, 320 respondents were sampled in this study. This number takes into account the prospect that there will be some altitude of non-response from respondents. 
INTERNATIONAL JOURNAL OF ACADEMIC RESEARCH IN BUSINESS AND SOCIAL SCIENCES Vol. 8, No. 9, Sept. 2018, E-ISSN: 2222-6990 @ 2018 HRMARS

\section{Measures}

The Occupational Stress Inventory Revised Edition- OSI-R developed by Osipow \& Davis (1998) was used to assess occupational stress. Occupational stress was measured using a 53 item scale made up of three dimensions namely Occupational Role, Personal Strain and Personal Resources. The OSI-R is a self-report inventory consisting of all three dimensions of occupational stress. Each of the three is composed of five-point Likert scale items (strongly agree, agree undecided, disagree and strongly disagree). The three dimensions are further segregated into the following scales:

- Occupational Roles Questionnaire (ORQ) measures the amount of stress provoked by the employment roles.

- Personal Strain Questionnaire (PSQ) is sub-divided into four subscales measuring the results of the occupational stressors, as manifested in personal strain.

- Personal Resources Questionnaire (PRQ) comprises of four sub scales and it measures coping instrument utilized by the subject. The subscales calculated comprise exercise, self-care, community support, and impartial/cognitive coping.

Statement that assess ORQ, PSQ and PRQ include; "At work I am expected to do many different tasks in too little time", "I don't seem able to get much done at work", and "When I need a vacation I take one", respectively.

Employee performance was measured using a composite of Spector's (1985) nine dimensions of job satisfaction consisting of 36 items. Each item on a 6-point Likert scale ranged from 1(disagree very much) to 6 (agree very much). An illustrative item is "Those who do well on the job stand a fair chance of being promoted"

The Cronbach's alpha for ORQ was (0.736), PSQ (0.737), PRQ (0.712) and that of Spector's job satisfaction scale was (0.604) indicating high levels of internal consistency for the instruments.

\section{Results of the Study Factor Analysis}

To assess factorability of data, Bartlett's test of sphericity and Kaiser-Meyer-Olkin (KMO) were also examined and it was determined that sphericity should be significant $(p<.05)$ and KMO value index which ranges from 0 to 1 should have a minimum value of .6 (Tabachnick \& Fidell, 2001). Components whose eigenvalues were greater than 1 were retained and as suggested by Stevens (1996) a factor loading of .60 was determined as a cut-off point.

Once the above criteria were established, exploratory factor analysis was used to examine the scales used in the study. KMO for all the scales was between 0.535 and 0.587 and sphericity was significant at $5 \%$. The analysis confirmed that for all the scales considered to be included in this study, eigenvalues were greater than 1.

Table 1 shows the results of validity and reliability analyses for measurement scales. A factor analysis was first done for Occupational Roles with 27 items which were clustered to 6 factors. Personal Strain comprising 15 questions were clustered to 4 factors, 11 items on the Personal Resources scale were also clustered into 4 factors. Finally, Job Satisfaction with 36 items was clustered to 7 factors. Between 82.916 percent and 94.938 percent of variance was explained by the variables as indicated by the cumulative percentage. 
INTERNATIONAL JOURNAL OF ACADEMIC RESEARCH IN BUSINESS AND SOCIAL SCIENCES

Vol. 8, No. 9, Sept. 2018, E-ISSN: 2222-6990 @ 2018 HRMARS

Table 1: Principal Component Factor Analyses

\begin{tabular}{|c|c|c|c|c|c|c|}
\hline & & $\begin{array}{l}\text { EIGEN } \\
\text { VALUE }\end{array}$ & KMO & $\begin{array}{l}\text { BARTLETTS } \\
\text { TESTS }\end{array}$ & Cumulative \% & $\begin{array}{r}\text { Cronbach } \\
\text { Alpha }\end{array}$ \\
\hline Occupational & & 6.844 & & & & \\
\hline Roles & OR1 & & & & & \\
\hline \multirow[t]{5}{*}{ (27) } & OR2 & 6.066 & & & & \\
\hline & OR3 & 4.676 & & & & \\
\hline & OR4 & 3.044 & & & & \\
\hline & OR5 & 2.297 & & & & \\
\hline & OR6 & 1.483 & 0.535 & 746.491** & 90.411 & 0.736 \\
\hline Personal & & 5.747 & & & & \\
\hline Strain & PS1 & & & & & \\
\hline \multirow[t]{3}{*}{ (15) } & PS2 & 3.156 & & & & \\
\hline & PS3 & 2.108 & & & & \\
\hline & PS4 & 1.426 & 0.550 & $621.805^{* *}$ & 82.916 & 0.735 \\
\hline Personal & & 3.144 & & & & \\
\hline Resources & PR1 & & & & & \\
\hline \multirow[t]{3}{*}{ (11) } & PR2 & 3.086 & & & & \\
\hline & PR3 & 1.843 & & & & \\
\hline & PR4 & 1.542 & 0.587 & $740.689 * *$ & 87.407 & 0.712 \\
\hline Job & & 7.151 & & & & \\
\hline Satisfaction & JS1 & & & & & \\
\hline \multirow[t]{6}{*}{ (36) } & JS2 & 7.021 & & & & \\
\hline & JS3 & 6.536 & & & & \\
\hline & JS4 & 4.463 & & & & \\
\hline & JS5 & 3.942 & & & & \\
\hline & JS6 & 3.166 & & & & \\
\hline & JS7 & 1.898 & 0.676 & $885.035^{* *}$ & 94.938 & 0.604 \\
\hline
\end{tabular}

**indicates significance at .05

\section{Relationship between Study Variables}

The correlation matrix as presented in Table 2 shows the degree of association between the variables of this study that is, occupational stress and employee performance. The correlation matrix shows a significant relationship between the dependent and independent variables. Table 2 shows that PS is negatively and significantly correlated with employee performance $(r=-0.682, p<0.01)$. On the other hand PR is significantly and positively correlated with employee performance $(r=0.040, p<0.000)$. The results further demonstrate a positive significant relationship between $O R$ and employee performance $(r=0.060, p<0.01)$. 
INTERNATIONAL JOURNAL OF ACADEMIC RESEARCH IN BUSINESS AND SOCIAL SCIENCES

Vol. 8, No. 9, Sept. 2018, E-ISSN: 2222-6990 @ 2018 HRMARS

Table 2: Correlation Matrix

\begin{tabular}{|c|c|c|c|c|c|c|c|c|}
\hline & EMP & PS & PR & OR & GENDER & AGE & EDU & MARITAL \\
\hline EMP & \multicolumn{8}{|l|}{-} \\
\hline PS & $-0.682 * *$ & \multicolumn{7}{|l|}{-} \\
\hline PR & $0.040 * *$ & $0.270 * *$ & - & & & & & \\
\hline OR & 0.060 & 0.011 & $\begin{array}{l}0.464 * * \\
-\end{array}$ & - & & & & \\
\hline GENDER & $-0.272^{* *}$ & $0.490 * *$ & $0.253^{* *}$ & $\begin{array}{l}0.336 * * \\
-\end{array}$ & \multicolumn{4}{|l|}{-} \\
\hline AGE & $0.593 * *$ & $-0.194^{*}$ & 0.105 & $\begin{array}{l}0.333^{* *} \\
-\end{array}$ & $0.329 * *$ & \multicolumn{3}{|l|}{-} \\
\hline EDU & -0.030 & $0.184^{*}$ & $0.179 *$ & $0.421 * *$ & 0.075 & $0.256 * *$ & \multicolumn{2}{|l|}{ - } \\
\hline MARITAL & $0.759 * *$ & $-0.727^{* *}$ & -0.095 & $\begin{array}{l}0.111 \\
-\end{array}$ & $-0.434 * *$ & $0.200 * *$ & $0.304^{* *}$ & - \\
\hline SERVICE & -0.138 & $0.620 * *$ & $0.339 * *$ & $0.202 * *$ & $0.578 * *$ & $0.489 * *$ & $0.445^{* *}$ & $-0.501^{* *}$ \\
\hline \multicolumn{9}{|c|}{$\begin{array}{l}\text { Note: OR represents Occupational Roles, PS repr } \\
\text { Resources, and EMP represents Employee Perfor } \\
\text { Standard Deviation. } N=320 \quad{ }^{*} p<0.05,{ }^{* *} p<0.01\end{array}$} \\
\hline \multicolumn{9}{|c|}{$\begin{array}{l}\text { To test the hypotheses of the study, data was analyzed using multiple linear regression analysis. Th } \\
\text { purpose of regression analysis is to relate a dependent variable to a set of independent variables. } \\
\text { order to examine the impact of occupational stress (independent variable) on employee performanc } \\
\text { (dependent variable), a multiple regression analysis was employed. The demographic characteristi } \\
\text { of the respondents such as age, gender, marital status, educational qualification and length of servic } \\
\text { were controlled for. } \\
\text { Table 3: Occupational Stress and Employee Performance }\end{array}$} \\
\hline \multicolumn{9}{|c|}{ DEPENDENT VARIABLE: EMPLOYEE PERFORMANCE } \\
\hline & & \multicolumn{2}{|c|}{ Coefficients } & \multicolumn{2}{|c|}{ Std. Err. } & $\mathbf{t}$ & \multicolumn{2}{|l|}{$\mathbf{P}$} \\
\hline \multicolumn{2}{|c|}{ Constant } & \multicolumn{2}{|l|}{-2.351} & \multicolumn{2}{|l|}{0.501} & -4.69 & 0.000 & \\
\hline AGE & & 0.907 & & 0.220 & & 4.12 & 0.000 & \\
\hline GENDER & & -0.244 & & 0.146 & & -1.67 & 0.097 & \\
\hline EDUCAT & & 0.015 & & 0.111 & & 0.13 & 0.895 & \\
\hline MARITA & & 1.021 & & 0.228 & & 4.48 & 0.000 & \\
\hline SERVICE & & 0.413 & & 0.191 & & 2.16 & 0.032 & \\
\hline STRESS & & -0.004 & & 0.001 & & -4.69 & 0.000 & \\
\hline$F(6,1$ & & & ר. & & & & & \\
\hline Prob $>F$ & & & 0.00 & & & & & \\
\hline R-square & & & 0.836 & & & & & \\
\hline Adj. R-sc & sared & & 0.830 & & & & & \\
\hline Root MS & & & 0.4112 & & & & & \\
\hline
\end{tabular}


INTERNATIONAL JOURNAL OF ACADEMIC RESEARCH IN BUSINESS AND SOCIAL SCIENCES Vol. 8, No. 9, Sept. 2018, E-ISSN: 2222-6990 @ 2018 HRMARS

Note: Gender and Marital status are dummy variables coded as 0 for male/Married and 1 for female/single

\section{Occupational Stress and Employee Performance}

As shown in Table 3 above, the $F$ statistics of 141 with a probability value of 0.000 less than 0.05 indicates the significance of the regression model in explaining the changes in employee performance. Additionally, the coefficient of determination which is the R-square value of 0.8368 implies that 83.68 percent of the changes in employee performance are explained by the regression model.

As shown in Table 3, age, gender, marital status, length of service and stress were establish to be significantly associated to employee performance. Age showed a significant positive relationship with worker performance at a significance level of $1 \%$ implying older bank employees perform better compared to younger bank employees. The coefficient of 0.907 indicates that a unit increase in age results in 0.907 units increase in the performance of employees.

The gender of respondents exhibited a significant negative $(-0.244)$ relationship with employee performance implying that female bank employees perform less compared to male bank employees at $10 \%$ significance level.

The results from Table 3 shows that single bank employees perform better compared to their married counterparts. This relationship was positively significant at a $1 \%$ significance level with a coefficient of 1.021. This could be as a consequence of other responsibilities married workers have to perform outside work, thus, taking care of their spouses, children and other family matters which put a lot of strain on them, hence their low performance.

The length of service of bank employees had a positive significant relationship with employee performance. This could imply that bank employees who have spent longer periods within the banking sector have experiences to deal with various work situations, hence have higher productivity. A unit increase in the length of service for a bank employee enhances employee performance by 0.413 at a $5 \%$ significance level.

Sources of Occupational Stress and Employee Performance

Table 4: Occupational Roles and Employee Performance

\begin{tabular}{lcccc}
\hline \multicolumn{5}{c}{ DEPENDENT VARIABLE: EMPLOYEE PERFORMANCE } \\
\hline & Coefficients & Std. Err. & $\mathbf{t}$ & $\mathbf{P}$ \\
\hline Constant & -5.001 & 0.697 & -7.17 & 0.000 \\
AGE & 1.478 & 0.119 & 12.38 & 0.000 \\
GENDER & -0.247 & 0.098 & -2.53 & 0.012 \\
EDUCATION & 0.278 & 0.103 & 2.69 & 0.008 \\
MARITAL & 1.215 & 0.111 & 10.98 & 0.000 \\
SERVICE & -0.214 & 0.114 & -1.88 & 0.062 \\
OR & 0.017 & 0.004 & 4.71 & 0.000 \\
\hline F( 6, 165) & 135.05 & & & \\
Prob > F & 0.0000 & & & \\
R-squared & 0.8308 & & & \\
Adj R-squared & 0.8247 & & & \\
Root MSE & 0.41873 & & & \\
\hline
\end{tabular}


INTERNATIONAL JOURNAL OF ACADEMIC RESEARCH IN BUSINESS AND SOCIAL SCIENCES Vol. 8, No. 9, Sept. 2018, E-ISSN: 2222-6990 @ 2018 HRMARS

Observations 172

Note: Gender and Marital status are dummy variables coded as 0 for male/Married and 1 for female/single, OR represents Occupational Roles.

To observe the impact of the sources of occupational stress on employee performance, organizational roles and personal strain were used in a stepwise multiple regression. As shown in Table 4 above, occupational roles (OR) showed a significant positive influence on employee performance at 1percent significance level. Thus, with the clearly defined roles that characterizes activities in the banking sector, an increase in OR will lead to an increase in performance.

However, with the exclusion of length of service which exhibited a negative significant relationship with employee performance, all the other variables showed a positive significant relationship with employee performance.

Table 5: Personal Strain and Employee Performance

\begin{tabular}{lcccc}
\hline \multicolumn{5}{c}{ DEPENDENT VARIABLE: EMPLOYEE PERFORMANCE } \\
\hline Coefficients & Std. Err. & $\mathbf{t}$ & $\mathbf{P}$ \\
\hline Constant & -2.324 & 0.446 & -5.21 & 0.000 \\
AGE & 1.006 & 0.148 & 6.81 & 0.000 \\
GENDER & -0.326 & 0.096 & -3.41 & 0.001 \\
EDUCATION & 0.009 & 0.094 & 0.1 & 0.921 \\
MARITAL & 1.108 & 0.117 & 9.46 & 0.000 \\
SERVICE & 0.322 & 0.147 & 2.19 & 0.030 \\
PERSONAL STRAIN & -0.263 & 0.068 & -3.88 & 0.000 \\
\hline F( 6, 165) & 128.93 & & & \\
Prob > F & 0.0000 & & & \\
R-squared & 0.8242 & & & \\
Adj R-squared & 0.8178 & & & \\
Root MSE & 0.42684 & & \\
Observations & 172 & & \\
\hline
\end{tabular}

Note: Gender and Marital status are dummy variables coded as 0 for male/Married and 1 for female/single

From the results in Table 5, educational qualification of bank employees showed a positive relationship with employee performance, but the relationship was not significant. This means that the educational qualification of bank employees does not determine the way they will perform on the job.

As evidenced in Table 5, personal strain had a negative relationship with employee performance. At a 1 percent significance level, with a coefficient of -0.263 which indicates that a unit increase in the personal strain on bank employees reduces bank employees' performance by 0.263 units. From the previous table (i.e., Table 4), organizational role a source of occupational stress was positively related to performance and personal strain showed a negative relationship with performance, this result should serve as a guide to organizations that stress is not always bad and does not always reduce employees performance. 
INTERNATIONAL JOURNAL OF ACADEMIC RESEARCH IN BUSINESS AND SOCIAL SCIENCES Vol. 8, No. 9, Sept. 2018, E-ISSN: 2222-6990 @ 2018 HRMARS

\subsubsection{Coping Strategy and Employee Performance}

For the purpose of this research, coping strategy was used to moderate the effect of occupational stress on employee performance.

Table 6: Moderating Effect of Coping Strategy on Employee Performance

\begin{tabular}{lcccl} 
& Coefficients & Std. Err. & $\mathrm{t}$ & $\mathrm{P}$ \\
\hline Constant & -2.189 & 0.428 & -5.12 & 0.000 \\
AGE & 0.938 & 0.142 & 6.59 & 0.000 \\
GENDER & -0.148 & 0.101 & -1.46 & 0.147 \\
EDUCATION & 0.041 & 0.090 & 0.45 & 0.652 \\
MARITAL & 0.896 & 0.124 & 7.24 & 0.000 \\
SERVICE & 0.237 & 0.142 & 1.67 & 0.097 \\
PS & -0.293 & 0.065 & -4.49 & 0.000 \\
PSPR & -0.159 & 0.039 & -4.04 & 0.000 \\
\hline F(7, 164) & 123.1 & & & \\
Prob > F & 0.000 & & & \\
R-squared & 0.8401 & & & \\
Adj. R-squared & 0.8333 & & & \\
Root MSE & 0.40831 & & & \\
Observations & 172 & & & \\
\hline
\end{tabular}

Note: Gender and Marital status are dummy variables coded as 0 for male/Married and 1 for female/single, PSPR indicates the interaction of personal strain and personal resources.

As indicated in Table 6, PS had a significant negative influence on employee performance with a coefficient of -0.263 and a significant level of 0.000 . This means that PS a source of occupational stress reduces the performance of employees in the banking sector.

As evidenced by the negative relationship between personal strain and employee performance, personal resources was used as a coping strategy to moderate the negative effect of occupational stress on the performance of bank employees. As shown by the coefficient of PSPR -0.159, employing personal resources reduced the negative effect of -0.293 to -0.159 indicating that in the presence of personal resources; personal strain effect on employee performance is reduced. It can be inferred that coping strategy is a good stress management intervention which when used in organizations can help reduce the impact of occupational stress on employee performance.

\subsection{Discussion of Results}

\subsection{Occupational Stress and Employee Performance}

From Table 3, the results showed a negative significant relationship between occupational stress and employee performance $(r=-0.004, p<0.001)$, the regression analysis pointed out that the relationship linking occupational stress and employee performance was $(r=0.8368)$, which means that occupational stress can shape employee performance up to 83.68 percent. The finding confirms earlier studies by Schorr (2001), who stated that occupational stress causes setbacks in the workplace which negatively affect employee wellbeing and organizational productivity. According to Ahmed and Ramzan, (2013) stress in the work environment reduces the intention of employees to perform better 
INTERNATIONAL JOURNAL OF ACADEMIC RESEARCH IN BUSINESS AND SOCIAL SCIENCES Vol. 8, No. 9, Sept. 2018, E-ISSN: 2222-6990 @ 2018 HRMARS

in jobs, with the increasing level of stress, employees' tendency to work well also decreases. No doubt occupational stress is necessary for increasing performance of employees but up to a certain level. Also Jamal (2014) examined the influence of work stress on productivity based on four job stress factors (overload, conflict, ambiguity, and adequacy of resources). They concluded that the greater the stress the less productive the labour force. However this study showed that the $z$ (role overload, role ambiguity, and role conflict) of bank employees does not have a negative impact on their performance but rather a positive effect. This is as a result of where the study was undertaken thus the banking sector. In the banking sector, employees have clearly defined roles that characterize activities, their jobs are highly formalized and standardized hence they do not experience role ambiguity and role conflict which are major sources of occupational stress.

The results of this research are consistent with that of Kazmi et al., (2008), Kakkos and Trivellas (2011) and Sylvester et al., (2012), which also showed a negative relationship between occupational stress and employee performance. Sylvester et al., (2012) suggested that there are two forms of stress: functional and dysfunctional. While functional stress is positive, dysfunctional stress is not and their findings indicated that dysfunctional stress is most dominant in organizations.

The findings are also consistent with that of Tubre and Collins (2000), Tuten and Neidermeyer (2004) who also found a negative relationship between stress and performance. The study done by (Stacciarini \& Troccoli, 2004) shows that stress positive and constructive rather than performance destructive. Their study is not consistent with this study. This could be due to the geographical location of researchers.

Following the relevant discussion involving occupational stress and employee performance, one is inclined to conclude that on an average a negative relationship between occupational stress and employee performance should be expected in the Ghanaian Banking Sector. The findings considerably support the hypothesized negative relationship between occupational stress and employee performance.

\subsection{Moderating Effect of Coping Strategy on Employee Performance}

As evidenced from the findings, personal strain a source of occupational stress had a negative relationship with employee performance. At a $1 \%$ significance level, with a coefficient of -0.263 which indicates that a unit increase in the personal strain on bank employees reduces bank employees' performance by 26.3 percent. Personal resources were used as a coping strategy to moderate the negative effect of occupational stress on the performance of bank employees. As shown by the coefficient of PSPR -0.159, employing personal resources reduced the negative effect of -0.293 to 0.159 indicating that in the presence of personal resources; personal strain effect on employees' performance is reduced. The findings support the expected partial moderation effect of coping strategies on occupational stresses (that is, work performance relation).

The finding is consistent with the Transactional theory of Lazarus (1984), sometimes referred as the Cognitive-Relational approach. According to this theory the individual and their environment are perceived as coexisting in a vibrant relationship, where stress is the psychological and emotional condition that is internally represented as part of a stressful transaction. The two major concepts in this process are appraisal and coping.

Mark and Smith (2012) described numerous types of coping behaviours, and recommended that they could be aggregated into two key categories of coping response: problem-focused coping (attempts to cope using more realistic problem solving type approaches) or emotion-focused coping 
INTERNATIONAL JOURNAL OF ACADEMIC RESEARCH IN BUSINESS AND SOCIAL SCIENCES Vol. 8, No. 9, Sept. 2018, E-ISSN: 2222-6990 @ 2018 HRMARS

(emotional-oriented coping approaches) each of which are appropriate in diverse kinds of circumstances.

Most studies which found a moderating effect of coping identified problem-solving coping as a favourable coping style, while emotion-focused coping turned out as an unfavourable coping style (Parkes, 1990). Employees who approach stress directly or engage in other problem solving behaviours are better off than employees who concentrate on management of their emotions and cognition.

The Demand-Control model of Karasek's (1979) is consistent with the findings of this study which shows that those exposed to elevated levels of demand, as well as having low intensity of job control (high-strain situation) were disproportionately more likely to show increased levels of depression, fatigue, and cardiovascular disease and mortality. Nonetheless, the lowest levels of illness were in individuals with reasonable or even high demands if they also had high levels of job control (challenge situation). Karasek (1979) thus proposed an interaction where high demands and low control would forecast high strain, but that high control would buffer the negative effect of demands on outcomes. The inclusion of social support to the model suggested the importance of support from colleagues, family and management as a buffer in high demand situations. Thus, bank employees who perceive low occupational stress and high coping tend to have higher work performance. The moderating role of coping shows the effectiveness of coping strategies in the workplace.

However, the results of (Kitaoka-Higashiguchi et al., 2003) show that coping strategies will mediate between occupational stress and employee performance. For the purpose of this research, coping strategy was used as a moderator to reduce the negative effect of stress on the performance of employees.

The hypothesized positive relationship of coping strategies between occupational stress and employee performance was not confirmed. However, the hypothesized moderating role of coping strategy was confirmed.

\subsection{Conclusion}

Occupational stress is regarded as a growing trend and the understanding among bank employees of its ill effects is escalating. From the study, it can be stated that the impact of occupational stress on bank employees' performance is negative. However, occupational role a source of stress had a positive relationship with bankers' performance; conversely, personal strain also a source of occupational stress had a negative relationship with employees' performance. Hence occupational stress is regarded to be very essential in the workplace.

Inadequate stress makes an individual bored and propagates lack of interest in the work. High levels of occupational stress lead to bank employees' reduced performance. The banking industry needs to maintain optimal levels of stress in the workplace for employees to perform at the peak of their capabilities.

The banking industry is responsible for creating occupational stress; hence it should take appropriate measures in order to optimize the benefits of occupational stress faced by their bank employees.

Reducing occupational stress is largely a matter of good management practice, and requires employers and employees to work together for the common good. Both share a joint responsibility for reducing stress which, when successful can help employees to enjoy their work more and businesses to thrive as a result.

Finally, managing work related stress is a "real" issue and any organisation that seeks to create and preserve the finest state of physical, mental and social well-being of its employees needs to have 
INTERNATIONAL JOURNAL OF ACADEMIC RESEARCH IN BUSINESS AND SOCIAL SCIENCES

Vol. 8, No. 9, Sept. 2018, E-ISSN: 2222-6990 @ 2018 HRMARS

policies and procedures that meticulously address health and safety. These policies will comprise strategies to manage stress, based on the needs of the organisations and its employees, and will have to be recurrently reviewed and evaluated.

\subsection{Managerial Implications}

It is imperative for banks to recognize that both individual and organizational level interventions are required to ensure effective stress management for achieving increased organizational performance. The following recommendations are therefore made based on the study findings:

It is important to formulate comprehensive strategies for stress management. This may provide a more effective, broad- based intervention program that will address occupational stress related problems of bank employees, which can eventually lead to an improved level of employee performance.

The management of the Banks need to devise regular stress management programs tailored to meet the needs of bank employees. It may include workshops on life skills and stress coping techniques. Such programs should be evaluated to measure the effectiveness. The process should be well documented and monitored, with periodic follow-up.

Employee assistance programs, with the necessary access to counselling and therapy should be made available to all bank employees. This type of employee service would help to deal with occupational stress related to work, family and trauma, which may influence the employee's ability to perform optimally. Through proper training, development and feedback sessions bank employees will be able to enhance their skills and would also help them to cope better with the changes in their work environment.

A healthy standard of living within the organisation should be encouraged and endorsed. Management can for instance negotiate gym memberships at an exceptional price in order to promote physical exercise; recreational activities, inter and intra departmental competitions, group outings, giving regular breaks to employees between work hours are some of the steps management can adopt to reduce the levels of occupational stress faced by their employees. Also, the promotion of work-life balance and introduction of flexible work options such as paid parental leave, part-time work, flexible start and finish times, flexi days and job sharing is highly recommended.

It is of importance for management to provide support to bankers in the form of competent colleagues, coaches /mentors, and professional networks. As Reid (2016) mentioned that having friends and supporters in times of difficulty helps individuals see demanding events as less intimidating and more controllable than if they had little or no support. They can provide emotional and financial support at different times. Friends and supporters can also often suggest constructive strategies for dealing with the sources of stress. In addition, they can also assist ease the negative feelings that often come with exposure to demanding events. It is interesting to note that social support is a very effective stress management technique that can be used by bankers to reduce stress.

\subsection{Recommendations for Future Research}

The findings of this research suggest several avenues for future research. Occupational stress and employee performance appear to be useful areas for continued examination; it is for that reason significant to explore the influence of various demographic variables like age, experience, salary, and length of service on employees' performance. 
INTERNATIONAL JOURNAL OF ACADEMIC RESEARCH IN BUSINESS AND SOCIAL SCIENCES Vol. 8, No. 9, Sept. 2018, E-ISSN: 2222-6990 @ 2018 HRMARS

The researcher suggests longitudinal studies as these kinds of studies can provide a better insight into the effects of these variables on various forms of occupational stress and employee performance for enhancing effectiveness of the Banking sector.

\section{References}

Ahmed, A., \& Ramzan, M. (2013). Effects of job stress on employees job performance a study on banking sector of Pakistan. IOSR Journal of Business and Management, 11(6), 61-68.

Ashong, G. G. N. A., Rogers, H., Botwe, B. O., \& Anim-Sampong, S. (2016). Effects of occupational stress and coping mechanisms adopted by radiographers in Ghana. Radiography, 22(2), 112-117.

Ballard, A. (2016). Job Satisfaction and Stress Level of the Occupational Health Nurse. Gardner-Webb University.

Bhatti, M. A., Juhari, A. S., Piaralal, S. K., \& Piaralal, N. K. (2017). Knowledge Workers Job Performance: An examination of Career Values, Perceived Organizational Support and Career Satisfaction. Business and Management Horizons, 5(2), 13.

Bloom, E. M. (2014). Horizontal violence among nurses: experiences, responses and job performance.

Brock, B.L. \& Grady M. L. (2002). Avoiding burnout: A principal's guide to keeping the fire alive. Thousand Oaks, CA: Corwin Press.

Carayon, P., Hancock, P., Leveson, N., Noy, I., Sznelwar, L., \& Van Hootegem, G. (2015). Advancing a sociotechnical systems approach to workplace safety-developing the conceptual framework. Ergonomics, 58(4), 548-564.

Carlson, M. (2017). Performance: A critical introduction. Routledge.

Centre for Gender Studies and Advocacy, (2011). Promoting Decent Work for Women in the Banking and Domestic Sectors in Ghana: a national research dissemination and policy dialogue. Retrieved from_Endler N.S, and Parker J.D.A. (1999). Coping Inventory for Stressful Situations (CISS): Manual ( $2^{\text {nd }}$ ed.) Multi-Health Systems, Toronto

Cheung, I. O. L. (2016). An exploration of the stressors and coping factors of parents of children with autism spectrum disorder, with focus in the impact of christian faith and implications for local churches. Biola University.

Dartey-Baah, K., \& Ampofo, E. Y. (2015). Examining the influence of transformational and transactional leadership styles on perceived job stress among Ghanaian banking employees. International Journal of Business and Management, 10(8), 161.

Dua, J. K. (1994). Job stressors and their effects on physical health, emotional health and job satisfaction in a university. Journal of Educational Administration, 32, 59-78.

Eldor, L., Fried, Y., Westman, M., Levi, A. S., Shipp, A. J., \& Slowik, L. H. (2017). The experience of work stress and the context of time: Analyzing the role of subjective time. Organizational Psychology Review, 7(3), 227-249.

Farth, J., Dobbin, G., Cheng, B. (1991), "Cultural relativity in action: a comparison of self-ratings made by Chinese and US workers", Personnel Psychology, Vol. 44, pp.129-147.

Ghana Investment Promotion Centre, (2011). Investing in Ghana's financial sector.

Giga, S.I., \& Hoel, H. (2003). Violence and stress at work in financial services. Sectoral Activities Programme: Working Paper, WP.210.

Hair, J.F., Anderson, R.E., Tatham, R.L., \& Black, W.C. (2006). Multivariate data analysis. New Jersey: Prentice Hall International, Inc. 
INTERNATIONAL JOURNAL OF ACADEMIC RESEARCH IN BUSINESS AND SOCIAL SCIENCES

Vol. 8, No. 9, Sept. 2018, E-ISSN: 2222-6990 @ 2018 HRMARS

Hart P.M, Wearing A.J (1995). "Occupational stress and well being: a systematic approach to research, policy and practice", In: Cotton, P (Ed), Psychological Health In the Workplace

Ismail, M.I. and Hong, T.T. (2011). Identifying work related stress among employees in the Malaysian financial sector. World Journal of Management, pp. 229-243.

Jamal, M. (2014). Professional Commitment among Nurses as A Moderator Of Job Stress And Job Performance: An Empirical Examination In The Middle East. Middle East Journal of Nursing, 7(3).

Jamshed, K.K, Muhammad, A.K, Ayaz,U.H, Muhammad, A \& Amjad, A. M.(2011).Occupational stress and burnout in Pakistan's banking sector. African Journal of Business Management, 5(3), pp810-817

Kazmi, R. (2007). Occupational Stress and its Effects on Job Performance; A Case Study of Medical House Officers of District Abottabad, First Proceedings of International Conference on Business and Technology, Pages 182-186, Iqra University Islamabad

Kazmi, S. S. A., Hashim, M., Ullah, M., Manzoor, S. R., \& Khan, M. A. (2017). Impact Of Job Stress On Work Family Conflict: A Case Study Of Bankers Of Private Sector Banks In Peshawar, Pakistan.

Khamisa, N., Oldenburg, B., Peltzer, K., \& Ilic, D. (2015). Work related stress, burnout, job satisfaction and general health of nurses. International journal of environmental research and public health, 12(1), 652-666.

Kinman, G. \& Jones, F. (2001), "The work-home interface", In Jones, F. and Bright, J. (Eds), Stress: Myth, Theory and Research. Prentice-Hall, London.

Larson, E. A. (2004). The time of our lives: The experience of temporality in occupation. Canadian Journal of Occupational Therapy, 71(1), 24-35.

Lazarus, R.S. (1999). Stress and emotion: A new synthesis. New York: Springer.

Malik, N. (2011). A study of occupational stress experiences by private and public banks employees in Quetta city. African journal of business management, 5(8), pp.3063-3077.

Malta, A (2004). Stress at Work. A Concept in Stress. Human Factors Limited. Business Psychology and Strategy Development.

Mark, G., \& Smith, A. P. (2012). Occupational stress, job characteristics, coping, and the mental health of nurses. British journal of health psychology, 17(3), 505-521.

McGann, M., White, K., \& Moss, J. (2016). Labour casualization and the psychosocial health of workers in Australia. Work, employment and society, 30(5), 766-782.

McGrath, J.E. (1970) A conceptual formation for research on stress. In J.E. McGrath (ed.) Social and Psychological Factors in Stress, pp 10-12. New York

Meneze, M. M. (2005). The Impact of Stress on productivity at Education Training \& Development Practices: Sector Education and Training Authority (Master thesis, university of Pretoria, South Africa)

Mokdad, M (2005). Occupational stress among Algerian teachers: African Newsletter on Occupational Health and Safety; 14:46-47

Motowidlo, S.J., and Van Scotter, J.R. (2004). Evidence that task performance should be distinguished from contextual performance. Journal of Applied Psychology, 79, 475-480

Mwangi, S. M. (2015). The Effect of Work Related Stressors on Employee Performance in NonGovernmental Organizations In Kenya (Doctoral dissertation, United States International University-Africa). 
INTERNATIONAL JOURNAL OF ACADEMIC RESEARCH IN BUSINESS AND SOCIAL SCIENCES

Vol. 8, No. 9, Sept. 2018, E-ISSN: 2222-6990 @ 2018 HRMARS

National Institute for Occupational Safety and Health (2010), Stress at Work, U.S. Department Of Health and Human Services, Public Health Service Centers for Disease Control and Prevention Publication No. 99-101

Neuman, W.L. (2007). Basics of Social Research: Qualitative and Quantitative Approaches, $2^{\text {nd }}$ ed., Pearson Education: New York, pp.1811

Odoardi, G. (2016). The relationship of perceived human resources management practices and innovative work behavior (Doctoral dissertation, Bordeaux).

Ornelas, S. and Kleiner, B. H. (2003), New Development in Managing Job Related Stress, Journal of Equal Opportunities International, and 2(5): 64-70.

Osipow, S.H. and Davis, A. (1988). The relationship of coping resources to occupational stress and strain. Journal of Vocational Behaviour, 32, 1-15. OSI Model Pacific Grove, California: Brooks/Cole Publishing Company

Pallant, J. (2006). SPSS Survival Manual (2nd Ed.): A step by step guide to data analysis using SPSS .New York: Open University

Parikh, P, Taukari A, Bhattacharya T. (2004) Occupational Stress and Coping among Nurses. Journal of Health Management; 6: 115-27

Powell, M. (2018). Burnout, Role Ambiguity, and Coping Among MSW Students in Field Placement (Doctoral dissertation, Fordham University).

Quick, J. C., \& Henderson, D. F. (2016). Occupational stress: Preventing suffering, enhancing wellbeing. International journal of environmental research and public health, 13(5), 459.

Rebecca, M. (2010). Factors That Affect Employee Performance in an Organization

Reid, C. (2016). Railroading Black Families: African American Men, Family, and Labor in PostEmancipation Georgia.

Schorr, L. (2001). Coping with stress, boosting productivity. Employment News, 23-26.

Schultz, D. and Schultz, E.S. (2002). Psychology and Work Today. (8th Ed.). India: Pearson Education, Inc.

Siegrist, J. (2001). A Theory of occupational stress. In J. Dunham (Ed.) Stress in the workplace (pp.5266). Philadelphia, PA: Whurr

Spector, P.E. (1997) Job Satisfaction: Application, Assessment, Causes, and Consequences. Thousand Oaks, Calif: Sage Publications

Stevens, J. (1996). Applied multivariate statistics for the social sciences (3rd Ed.). Mahwah, NJ: Lawrence Erlbaum.

Suliman, A. (2001), "Work performance: is it one thing or many things? The multidimensionality of performance in a Middle Eastern context", International Journal of Human Resource Management, Vol.12, No 6, pp.1049-1061.

Sutherland, V. J., \& Cooper, C. L. (2000). Strategic Stress Management. London: Palgrave

Sylvester, C. M., Corbetta, M., Raichle, M. E., Rodebaugh, T. L., Schlaggar, B. L., Sheline, Y. I., ... \& Lenze, E. J. (2012). Functional network dysfunction in anxiety and anxiety disorders. Trends in neurosciences, 35(9), 527-535.

Tabachnick, B. G. and Fidell, L. S. (2007). Using Multivariate Statistics (3rd Ed.). New York, New York: HarperCollins.

Trivellas, P., Kakkos, N., Blanas, N., \& Santouridis, I. (2015). The impact of career satisfaction on job performance in accounting firms. The mediating effect of general competencies. Procedia Economics and Finance, 33, 468-476. 
INTERNATIONAL JOURNAL OF ACADEMIC RESEARCH IN BUSINESS AND SOCIAL SCIENCES Vol. 8, No. 9, Sept. 2018, E-ISSN: 2222-6990 @ 2018 HRMARS

Tsai, L. C. F., Nolasco, C. A. R., \& Vaughn, M. S. (2017). Modeling job stress among police officers: interplay of work environment, counseling support, and family discussion with coworkers. Police Practice and Research, 1-17.

Tubre, T., \& Collins, J. (2000), "Revisited: a meta-analysis of the relationships between role ambiguity, role conflict, and job performance", by Jackson and Schuler (1985), Journal of Management, Vol. 26, pp. 155-169

Van Scotter, J.R., Motowidlo, S.J., \& Cross, T.C. (2000), "Effects of task and contextual performance on systematic rewards", Journal of Applied Psychology, Vol. 85 No 4, pp.526-535.

Venugopal, V., Chinnadurai, J., Lucas, R., Vishwanathan, V., Rajiva, A., \& Kjellstrom, T. (2016). The Social Implications of Occupational Heat Stress on Migrant Workers Engaged in Public Construction: A Case Study from Southern India. International Journal of the Constructed Environment, 7(2).

Wan, Y. K. P., Wong, I. A., \& Kong, W. H. (2014). Student career prospect and industry commitment: The roles of industry attitude, perceived social status, and salary expectations. Tourism Management, 40, 1-14.

Wright, T.A., \& Cropanzano, R. (2000). Psychological well-being and job satisfaction as predictors of job performance. Journal of Occupational Health Psychology, 5, 84-94 